\title{
Post-war Maudsley personalities
}

\author{
Sidney Crown, Consultant Psychiatrist, The London Hospital, London E1 1BB
}

The 100th Annual Dinner of the Gaskell Club for Winners of the Gold Medal was held at the Royal College of Psychiatrists on 30 October 1987.

Looking round the tables I was struck by the number of people who had worked at the Maudsley, a tangible reminder of the contribution of that centre of excellence to psychiatry.

I do not doubt that the standard of psychiatry at the Maudsley remains as high as it ever has been, but inevitably my thoughts ran to the post-war period when, as a 21 year old, it seemed one was surrounded by giants.

In a sense this was true for medicine as a whole; certainly those who went to the National Hospital, Queen Square, for a valued six-month neurological attachment returned with breathless accounts of the larger-than-life personalities there!

My own introduction to psychiatry arose because my father, a GP with an interest in psychiatry, had worked in the Emergency Medical Services in the war together with those members of the Maudsley who had been transferred to Mill Hill Emergency Hospital. Through him I was introduced to $\mathrm{Dr}$ William Sargant and the Insulin Coma Ward. Looking back I cannot decide whether this introduction was a trauma or a conversion experience. I vividly remember patients waking from their coma to be exhorted to get better. All that effort, all that complicated training of the nurses to look after patients in deep coma, all that drama spoiled when Brian Ackner demonstrated that insulin coma was no more effective than placebo. It was my first introduction to the shattering power of the controlled trial to destroy treasured illusions.

Related perhaps to the largeness of the people, the Maudsley itself seemed small and intimate - particularly departments one was most closely associated with. In my case, as a clinical psychologist, this was the Children's Department. The two consultants, Kenneth Cameron and William Gillespie, were contrasted. One , the fatherly Scotsman, reassured parents that they should "carry on the way they were going" while the other, psychoanalytic and passive, neither reassured parents nor, of course, guided them!

Another factor that made the Maudsley seem small was that many of the junior staff lived in the hospital or nearby and spent hours - literally hours socialising. Parties were fairly hectic and on one frightfully remembered occasion we picked up a colleague at the bottom of stone stairs, deeply unconscious, with CSF dripping from his nose and took him across the road to King's College Hospital. To reassure those who want to know, he made an excellent recovery and remains a leading European psychologist who had better be nameless!

On a more cheerful note, the Christmas concert was always a memorable event. A particular 'hit' number was D. L. Davies and R. W. Tibbetts, who in life were small, round and looked extraordinarily alike, as Tweedle Dum and Tweedle Dee. The cricket team (see picture) was impressive despite the presence of so many unlikely analysts: Michael Fordham, Gordon Prince, Murray Jackson, Peter Hildebrand and-surely a unique snap-R. D. Laing. Bob Hobson was a stylish opening batsman in the manner of Winston Place, the Lancashire professional with whom he had been at school. No boundaries before lunch! Cricket was of considerable interest and Michael Shepherd, Bob Hobson and I regarded ourselves as afficionados and encyclopaedias of the subject although, sadly, only moderate performers. In the Psychology Department 'personality' was everything, with Eysenck's nomothetic approach with a cast of hundreds contrasting vividly with Monte Shapiro's intensive studies of the individual case. With D. W. Furneaux's development of speed-power intelligence tests, sophistication was introduced to challenge the largely unchallenged concept of the 'global' IQ.

A third fact which perhaps added to the apparent cosiness of the Maudsley was that many of the senior consultants had worked together closely in the emotionally highly-charged atmosphere of war so that what might be styled as a "complex group psychodynamic" existed between them. Defined roles were established on such criteria as being brilliant as opposed to merely extremely clever; enthusiastic clinician versus thinker; psychodynamicist versus geneticist; straightforward, plain-speaking English clinician versus too-clever-by-half European neuropsychiatrist.

Even in this rarified atmosphere there were supergiants, none greater than Aubrey Lewis. Small in stature, overweight, permanently dressed in a navyblue suit, a 'school' white shirt and nondescript tie he had a baleful, unblinking stare which could reduce strong men, even those back from the services, to 
speechlessness. Although devastatingly critical, his criticism was never personal but concerned only with the high standards below which, to his constant regret, we fell. On one occasion I presented him with the first draft of a paper. "Frankly", he saidfrankly was a favourite word of his - "I think it's terrible..." His intellectuality was almost entirely out of touch with reality as understood by more ordinary persons. I remember, as one of his research assistants, being invited to lunch when a visiting professor of psychology from the United States was the guest. Aubrey Lewis aimed to put him at ease by discussing matters from the contemporary American scene: he chose American poetry. I still remember the bemused look on Roger Russell's face.

Nowadays there are many professors of psychiatry but there were few established chairs at that time. Aubrey Lewis, with a combination of sincerity and irony, always used to refer to Professor D. K.
Henderson as "The most distinguished psychiatrist in the United Kingdom". We were unconvinced.

An abiding memory is the combination of total commitment aligned to terror which preceded the Monday Morning Conference which was attended meticulously by every consultant in all specialities. Registrars used to prepare by listening to each other's presentation. I remember once when a patient's history involved saying that he had some unspeakable thoughts as he passed a Lyons Corner House imitating the great man by saying "which branch". The following week he asked exactly that!

H. J. Eysenck was, of course, the psychologists' favourite guru. Psychiatrists who think of him in recent years as a remote, ivory-tower figure, permanently with a dictating machine in a study lined with books presented to him by psychologists from all over the world, could not conceive the relaxed friendly, approachable caring person that he was to

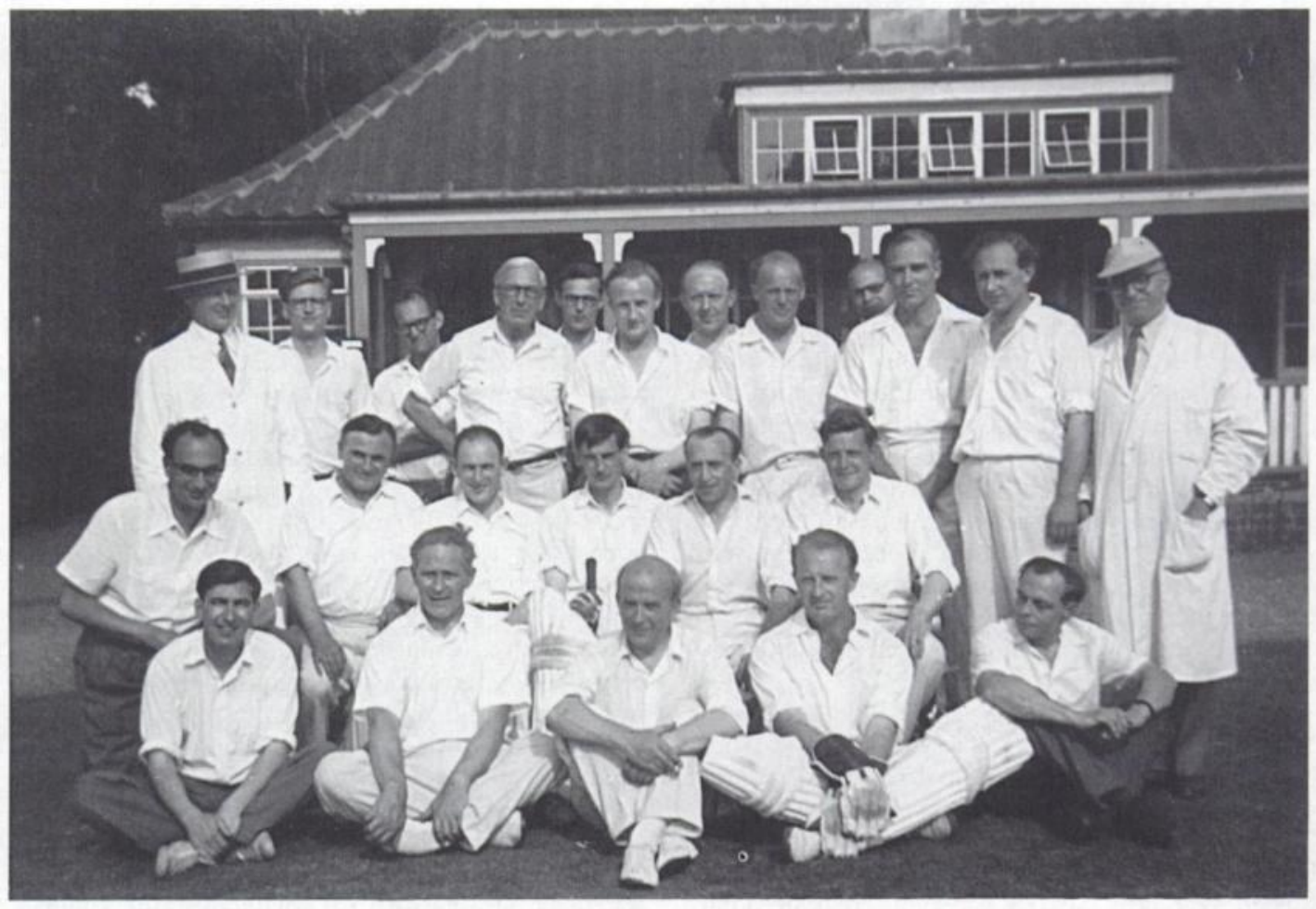

From left to right

Back row, standing: Jack Hobson, next two people unidentified, John Layard, next person unidentified, Anthony Storr, David Howell, R. D. Scott, James Anthony, Alan Edwards, Eric Brenman and Raymond Gledhill.

Middle row, seated: Ted Goldblatt, Kenneth Lambert, Julius Guild, David Malan, G. S. Prince and R. F. Hobson.

Front row, seated: Peter Hildebrand, Michael Fordham, Robert Moody, Murray Jackson and R. D. Laing. 
us. He pushed us and backed us unreservedly: I once received a letter from the secretary of an International Conference on Psychiatry accepting a paper I had not offered but Hans had on my behalf. He said he forgot to tell me!

Eysenck was the king of programme research. The $\mathrm{PhD}$ students knew exactly what they were to do for two years and, unlike today, expected to gain their degree after that time. Eysenck was just beginning to build his $\mathrm{PhD}$ list at that time. I saw it recently. It is enormously long and I am proud to say I lay third on it. It includes an exceptionally talented group who now occupy chairs of psychology all over the world, as well as a sub-group who did fairly numerate researches at that time and then disappeared into psychoanalysis or psychotherapy. Joe Sandler, Peter Hildebrand, Head of Psychology at the Tavistock Institute, Victor Kanter and myself are among them. H. Gwynne Jones became president of the British Psychological Society; Ann and Alan Clarke helped to put mental handicap ('subnormality') on the map. Psychometrics was at its height and it is amusing now to realise that if you ask a candidate for the MRC Psych anything about psychological tests they either regard the question as unfair, and make this obvious, or say that tests are "no good". An enormously overweight American psychometric psychologist, Ardie Lubin, who worked with L. L. Thurstone in Chicago, taught us statistics, how to use "calculating machines', and how to lay out our data so as to check and find mistakes: if we found one everything was done again. I have many times sat in front of sheets of squared paper covered with analyses of variance and co-variance virtually in tears because some complex cross-check had revealed an error. We were literally not allowed to go home until we had found it. But at least we thought about what we were doing and why. My impression now is that computer 'packages' have stopped people thinking.

The second major figure in the psychology department was M. B. Shapiro, still in RAF uniform when I first met him, tall, with black curly hair and a curiously stiff appearance because one shoulder had been immobilised by parts of a cannon shell. A very different temperament from Eysenck and possibly partly in reaction to all the programme research, he was busily inventing the systematic study of individual patients. In a recent letter to me, Monte Shapiro pointed to the extraordinary range of age and experience at the Maudsley at that time. The clinical section of the psychology department, for example, of eight people four were ex-RAF aircrew and two of these were ex-POWs. One of these, the charismatic Vic Meyer, involuntarily introduced me early to the notion that behaviourism did not make due allowance for the all-pervading influence of 'personality'.

Despite the academic pressure and the constant self-criticism, one of the nicest aspects of the
Maudsley at that time was the courtesy afforded to juniors by many of the senior staff. Emanuel Miller was the model of a Jewish intellectual, with a large head, made larger by thick, grey hair and a large nose and a grave, thoughtful, kindly manner that, without a trace of condescension, somehow elevated you to his level. Erich Guttman was another thoughtful person. My research at the time involved the psychological testing of patients at St Bernard's Hospital. Guttman insisted on accompanying me on the trolleybus to Southall in order to introduce me to Dr J. B. S. Lewis, one of those highly respected medical superintendents of the time. Benevolent despots certainly, unthinkable in the present climate, but life did seem to work smoothly. Especially of course for a centre like the Maudsley which could always transfer ('get rid of') troublesome patients at the drop of a hat or at least following a polite request on the telephone.

With increasingly common interests, academic and clinical boundaries have become blurred. At that time there seemed to be a number of 'natural' groupings. Clinical psychiatry was, of course, strongly represented by Lewis, Sargant, Slater, Curran, D. L. Davies, Blacker and others. The ex-refugee, learned European neuropsychiatrists were represented by Stengel, Guttman, Mayer-Gross and E. Meyer. There was an obvious 'eclectic' group led by Emanuel Miller and Denis Hill. The psychoanalysts were a powerful sub-group, far surer of their identity and less beleaguered than now, and represented particularly by Foulkes, W. C. M. Scott (who could carry on a conversation with an autistic child which the child obviously understood but no-one else in the room did) and Gillespie. The neuropathologists linked with the neurosurgeons and held a remarkable teach-in every Saturday morning led by Murray Faulkner and Sir Charles Symonds. Symonds represented for me then, and still does, the nearest thing I have ever experienced to pure intellect without any interference from emotion!

At the time the Maudsley had a highly talented 'junior' staff but it is hard to think of them now as ever 'junior'. Martin Roth, Stafford-Clark, John Marshall, Alick Elithorn, Bob Hobson, John Harrington, R. B. Sloane, Anthony Storr, KräuplTaylor, E. J. Anthony, Joe Redfern, Michael Shepherd, Malcolm Pines, Murray Jackson give the flavour of it! James Anthony had the enviable reputation of being able to twist Aubrey Lewis around his little finger; perhaps that was because they lived in the same part of London and travelled together.

Even in this company possibly the most charismatic character was Henri Rey, a Barts-trained professional Frenchman who, like other famous Frenchmen, retained his beautiful accent. At a time when psychoanalysts bothered even less than now to 'communicate' Henri was everyone's guide to the 
mysteries of dynamic psychiatry. He also had the strange air of being an entirely and totally Maudsley man. I once asked him when he came to the Maudsley to which he replied, "I was born in the Maudsley"which I almost believed.

This period saw the introduction of exciting research interests and research units. Lewis' brainchild, the Social Psychiatry Research unit, was formed with psychiatrist/barrister Morris Markowe at its head and with Jack Tizard and Neil O'Connor as collaborators. Suicidology was virtually invented by Peter Sainsbury. He and I beavered away in a tiny room in the basement: little did I realise the implications and ramifications and influence of that earlier Maudsley Monograph. Kräupl-Taylor, a numerate group-psychotherapist, was early into attempts at objective measurement: I learned of the predictive power of sociometric diagrams so that when a patient became dominant and unpopular he or she soon left the group. Although there were eminent individual forensic psychiatrists in the 'outside world', forensic psychiatry as an academic discipline began with Peter Scott and Trevor Gibbens, the latter later to occupy a chair in the subject. The first systematic attempt to compare techniques of leucotomy was made by the neurosurgical unit with which I was loosely connected. Ethical committees of the present would be horrified to know that three operations were assigned using my table of random numbers, the rationale, acceptable at the time, being that there was no clear evidence which technique was 'the best'.

I cannot pretend that these notes are anything other than somewhat arbitrary memories of a period, almost certainly distorted by emotion and in no sense 'history'. If I have been inaccurate or unfair I can only apologise. 